\title{
Konsep Kepemimpinan Pada Sosial Media Guna Menghasilkan Kategori
}

\author{
Setyo Budi \\ Program Studi Sistem Informasi, Universitas Dian Nuswantoro
}

\begin{tabular}{ll}
\hline \hline Article Info & ABSTRAK \\
\cline { 2 - 3 } Article history: & Kekuatan terbesar dalam perubahan kehidupan adalah teknologi informasi, \\
Received Jun $12^{\text {th }}, 2021$ & dan perubahan besar ini selalu disertai dengan kekuatan manusia dalam \\
Revised Aug $20^{\text {th }}, 2021$ & menciptakan sesuatu yang dapat dimanfaatkan untuk kehidupan, sehingga \\
Accepted Aug $31^{\text {th }}, 2021$ & fungsi teknologi tersebut dapat mengubah seluruh pola pikir, sikap dan \\
& karakter. Telah dikemukakan sebelumnya bahwa ada 3 tipe kepemimpinan, \\
& dan di jurnal ini terdapat 2 tipe kepemimpinan di sosial media yang merupakan \\
Keyword: & lanjutan dari penelitian sebelumnya, sehingga total ada 5 tipe kepemimpinan \\
Sistem kepemimpinan & yang menjadi pedoman dasar dalam mengembangkan kepemimpinan di social \\
Ketergantungan & media. Permasalahan yang dibahas disini adalah terjadinya kesenjangan \\
Pasif-agresif & komunikasi antara tokoh dengan masyarakat, dan yang paling parah adalah \\
Komunikasi & adanya hoaks dan kalimat yang dapat menimbulkan kontroversi. Seorang \\
& pemimpin harus mampu mengubah cara berkomunikasi dan dapat mengubah \\
& sikap-pola pikir serta karakter masyarakat sehingga dapat memberikan \\
dampak positif bagi keseluruhan kehidupan dalam kehidupan sehari-hari. & Metode yang digunakan disini adalah analisis; mengamati dan mempelajari \\
& beberapa literatur sebagai panduan. Hasil akhir yang diperoleh adalah \\
bagaimana komunikasi di social media dapat berubah menjadi lebih positif dan \\
dapat memberikan contoh dalam penerapannya, solusi dan kontribusi \\
perubahan yang dapat membantu meningkatkan kesejahteraan masyarakat, \\
dari sikap, pola pikir dan budaya, dan ini tentunya diharapkan oleh semua \\
pihak, berubah secara positif.
\end{tabular}

Copyright (C) 2021 STMIK Triguna Dharma. All rights reserved.

\author{
Corresponding Author: *First Author \\ Nama : Setyo Budi \\ Program Studi : Sistem Informasi \\ Afiliasi : Universitas Dian Nuswantoro \\ Email: setyobudi@dsn.dinus.ac.id
}

\section{PENDAHULUAN}

Sosial media mengubah perspektif, paradigma dan komunikasi. Sosial media merupakan gaya hidup sehari-hari yang tidak dapat dipisahkan dari setiap manusia di zaman ini. Perubahan ini memberikan dampak, baik secara positif maupun negatif. Permasalahan-permasalahan yang timbul di sosial media demikian banyak, sehingga pengontrolannya menjadi sulit dan mungkin tidak dapat dikendalikan keseluruhan, contohnya: hoax dalam berita, kalimat-kalimat yang tidak baik, informasi yang sangat kurang tetapi sudah di deliver kepada pengguna sosial media sehingga terjadi kesalahapaham, dan masih banyak sekali permasalahan yang timbul di sosial media, tetapi di dalam jurnal ini, masalah utama yang ingin dibahas adalah masalah kepemimpinan, dimana terkadang komunikasi yang dilakukan oleh pemimpin tidak dapat dipahami oleh pengguna sosial media, sehingga terjadi kesalahpahaman yang berkelanjutan dan mungkin tidak pernah ada penyelesaian untuk hal tersebut.

Di sini tantangan timbul, yaitu bagaimana seorang pemimpin dapat mengkomunikasikan visi dan misinya secara terarah dan secara positif dapat membangkitkan inpirasi positif untuk melakukan sesuatu yang bermanfaat bagi kehidupan masyarakat di sekitarnya. Sebagai contoh, perubahan dapat timbul pada saat perubahan itu sendiri diberikan sebuah solusi dan contoh konkrit di dalam penerapan, hal ini dapat dipermudah dengan kalimat: seseorang yang memiliki tujuan yang benar tetapi menggunakan cara yang salah dalam 
menyelesaikan masalah, maka akan dapat menimbulkan kesalahpahaman, oleh sebab itu, tujuan yang benar harus selalu sejalan dengan cara yang benar. Jurnal ini merupakan pengembangan dari jurnal Pengembangan dan implementasi dari wise netizen (e-comment) di Indonesia; dimana dalam jurnal ini dikatakan bahwa apa yang dikatakan wise adalah bijaksana di dalam bersosial media, mampu memberikan solusi dan perubahan positif di dalam interaksi sosial[1]. Berikutnya adalah jurnal Developing leadership systems inside university using Jim Collins method [good to great]: People management development to face ASEAN economic community in Indonesia[2], dimana di dalam jurnal ini, terdapat beberapa ciri kepemimpinan yang dapat diterapkan di sosial media. Dari kedua jurnal ini dikembangkan hal lebih lanjut seperti 5 tipe kepemimpinan di sosial media yang merupakan dasar dari kepemimpinan yang seharusnya ada di dalam sosial media. Hasil dari jurnal ini adalah bagaimana komunikasi seorang pemimpin dapat diterima dan mempengaruhi secara positif masyarakat sehingga dapat tercipta sebuah budaya positif, yang dapat memberikan kontribusi positif bagi kehidupan manusia.

\section{METODE PENELITIAN}

Beberapa literatur, analisis beberapa kejadian di sosial media, beberapa contoh kalimat yang terdapat di dalam sosial media, statemen-statemen yang dapat memberikan dampak positif dan negatif, keseluruhannya dianalisis dan kemudian dibuat sebuah framework dan/atau metode penelitian yang digunakan dalam jurnal ini.

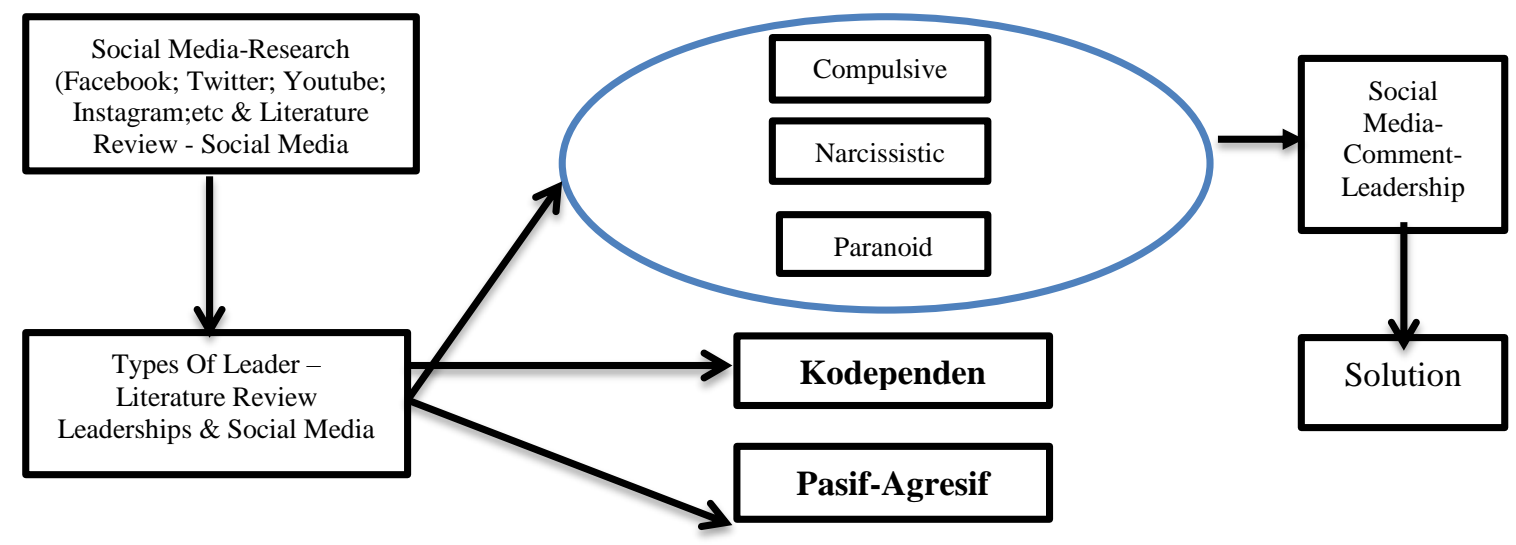

Gambar 1. Research Methods Social Media - Leadership Interlligence (LI) framework-The complete Types of leaderships

Pada gambar 1, kita dapat melihat bahwa proses awal adalah menganalisis sosial media yang telah ada pada saat ini, kemudian literatur-literatur yang berhubungan dengan sosial media dan kepemimpinan, selanjutnya menganalisis literature rievew dari beberapa konsep kepemimpinan secara umum. 3 (tiga) tipe kepemimpinan yang pertama adalah kompulsif, narsisistik, dan paranoid, dan sekarang akan dibahas 2 tipe kepemimpinan yang terakhir, yaitu kodependen dan pasif-agresif. Tahap akhir adalah bagaimana kedua tipe kepemimpinan ini dapat memberikan dampak positif kepada masyarakat dan juga efek apa yang dapat diberikan kepada masyarakat melalui social media. Beberapa test dilakukan untuk dapat mengetahui apakah termasuk tipe kodependen atau pasif-agresif, dan beberapa pemahaman awal yang harus dipahami adalah:

(1) penelitian kepemimpinan sekali lagi berubah fokusnya pada fenomena etika kepemimpinan di perusahaan aspek yang berbeda. Dengan demikian, banyak pendekatan baru dalam kepemimpinan terhubung ke tema etis atau moral. Di antaranya adalah konsep kepemimpinan etis, yang mencoba mengukur secara empiris apa arti kepemimpinan etis[3]; (2) pemimpin menghadapi tantangan khusus untuk ditampilkan kepemimpinan etis terhadap orang-orang dari beragam budaya latar belakang[4]; (3) Kami berpendapat bahwa etika literatur iklim belum sepenuhnya menyelidiki proses oleh persepsi iklim etis yang berkembang dan telah cenderung untuk fokus pada aktor individu (seperti organisasi) bukan pada beberapa aktor secara bersamaan. Keterbatasan ini telah tercermin dalam penelitian sebelumnya, yang memiliki hampir desain cross-sectional yang digunakan secara eksklusif, membatasi inferensi kausal[4]; (4) Menginvestigasi pengaruh kepemimpinan etis pada perusahaan kinerja keuangan dan sosial, kami fokus pada pencapaian tujuan perspektif dari para pemimpin top 
menggunakan kepemimpinan etis sebagai alat untuk meningkatkan sumber daya spesifik perusahaan dan mewujudkan tujuan strategis perusahaan[5]; (5) Kepemimpinan memiliki implikasi penting bagi kelompok, organisasi, dan masyarakat. Ketika berhasil, konstituennya sejahtera. Ketika itu salah, tim kalah, tentara dikalahkan, organisasi goyah, dan masyarakat menderita[5]; (6) Inti dari kepemimpinan baru ini adalah kapasitas untuk pembuat keputusan organisasi untuk beroperasi secara efektif dan dengan cara yang bertanggung jawab secara sosial di bawah tekanan kepentingan yang berpotensi bertentangan seperti dari pemegang saham dan kekuatan pasar di satu sisi dan kekuatan tenaga kerja dan masyarakat pada umumnya di sisi lain. Jadi pertanyaan pertama muncul: di mana generasi baru pembuat keputusan terbaik dikembangkan?[6]; (7) Dukungan budaya dari enam gaya kepemimpinan spesifik ditunjukkan oleh masingmasing skor rata-rata dari efektivitas yang dirasakan dari gaya kepemimpinan[7]; (8) Pelatih kepala melakukan fungsi penting untuk keberhasilan tim dan biasanya bertanggung jawab atas kinerja tim[8]; (9) Terkadang disarankan untuk menjelaskan perubahan perilaku dalam hal perubahan selera secara inheren hampa karena perubahan residual yang tidak dapat dijelaskan dapat dijelaskan dengan mempostulasikan beberapa perubahan sesuai selera. Ini adalah sebuah kasus khusus dari argumen yang lebih umum bahwa 'budaya' adalah konsep hampa karena itu hanya 'label' yang diterapkan untuk menyamarkan ketidaktahuan kita akan efek residual[9]; (10) Tujuan komunikasi ini proses tidak hanya untuk meningkatkan informasi mengalir, tetapi juga meningkatkan pemahaman[10].

Dari pemahaman-pemahaman di atas, maka kita dapat menemukan bahwa kepemimpinan dan pengaruhnya akan dapat memberikan efek berantai kepada masyarakat, di sisi lain, kepemimpinan memiliki pengaruh dan komunikasi yang dapat mengubah sebuah lingkungan dan budaya dalam sosial media

\section{ANALISA DAN HASIL}

Dibawah ini adalah 2 tipe kepemimpinan dari 5 tipe kepemimpinan di sosial media serta standarisasi pemimpin dan solusi lain:

\subsection{Pemimpin Kodependen}

Kekuatan kodependensi itu besar sekali. Tidak seperti tipe-tipe kepemimpinan sebelumnya yang telah kita identifikasi (kompulsif, narsistik, dan paranoid), kodependensi tidak termasuk di dalam kategori kelainan kepribadian yang telah dikenal. Malahan ini merupakan suatu tipe dan perilaku yang lebih generik yang dapat dijumpai di dalam banyak tipe kepribadian yang berbeda dan dapat menjadi satu komponen dari banyak kelainan kepribadian yang berbeda. Belum ada definisi yang disepakati secara umum tentang kodependensi. Seperti pepatah mengatakan: "Suatu kondisi emosional, psikologis dan perilaku yang bertumbuh sebagai akibat dari pengalaman individu yang berkepanjangan dan memperlakukan, serangkaian peraturan yang menekan, peraturan-peraturan yang menghindari pengungkapan perasaan secara terbuka juga diskusi langsung masalahmasalah pribadi dan antar pribadi”. Walaupun kodependensi paling sering dikaitkan dengan orang-orang yang hidup dengan orang lain secara kompulsif bergantung pada sesuatu (seperti alkohol, obat-obatan, makanan, pornografi, dan lainnya), aspek penting lainnya dari kodependensi adalah sistem sosial yang berkembang di sekitar hubungan-hubungan tipe ini.

Keluarga yang kodependen beradaptasi dengan cara-cara yang berbeda untuk menyeimbangkan perilaku secara sosial tidak dapat diterima dan memalukan dari seorang pribadi yang dependen. Ini seringkali melibatkan peraturan-peraturan yang ketat, biasanya tidak diucapkan namun dipahami secara jelas, yang mendikte bagaimana keluarga itu harus berperilaku dan yang mengatur bagaimana pribadi yang kodependen diijinkan berkomunikasi dengan publik. Perilaku-perilaku coping ini perlu menyembunyikan perilaku pribadi yang kodependen dan membatasi orang yang kodependen dari memberi pengungkapan secara lengkap dan jujur tentang emosinya atau dari mendiskusikan masalah itu dengan siapapun. Ini mengakibatkan tekanan emosional yang menciptakan stres besar pada orang-orang kodependen.

Aspek lain dari kodependennsi adalah kecenderungan untuk bereaksi ketimbang memulai tindakan. Orang-orang yang kodependen bereaksi terhadap perilaku dan pribadi-pribadi yang kodependen. Mereka bereaksi terhadap rasa sakit, masalah, dan perilaku dari orang lain dalam upaya menyembunyikan masalahmasalah keluarga, dan mempertahankan ketentraman di dalam hubungan mereka. Orang-orang yang kodependen mengambil tanggung jawab pribadi atas tindakan-tindakan dan emosi-emosi dari orang lain, seringkali menyalahkan diri sendiri atas perilaku-perilaku orang lain yang keliru, dan umumnya mereka memiliki toleransi yang tinggi bagi perilaku yang aneh dari orang lain. Mereka akan bereaksi sejauh tidak melukai perasaan orang lain walaupun itu berarti prosesnya mereka melukai diri mereka sendiri. Bagaimanapun juga, untuk menghindari konfrontasi, mereka sering berlaku sebagai pendamai di antara kelompok-kelompok yang bermusuhan, orang-orang yang kodependen tampaknya sangat ramah, selalu bersedia memikul tugas lain, walaupun sampai pada titik yang berlebihan, kerena menolak bisa melukai perasaan orang lain. Akibatnya orang yang kodependen menjadi gudang kemarahan dan frustasi yang ditekan. Suatu skenario yang tipikal dapat mencakup pengajuan permintaan seseorang dari orang yang kodependen untuk memikul suatu proyek baru. Walalupun orang yang kodependen itu tidak mau memikul tanggun jawab 
tambahan, orang kodependen akan menerima tanggung jawab itu, agar tidak melukai perasaan orang yang mengajukan permintaan tersebut. Kemudian, setelah menerima tanggung jawab yang baru itu, orang yang kodependen itu akan menjadi marah dan mengatakan, "Saya tidak percaya mereka meminta saya, mereka menyangka saya kelebihan pekerjaan, ada apa dengan mereka?", sebenarnya, solusi yang sederhana bagi masalah orang yang kodependen itu adalah: "tidak, terima kasih" yang sopan dan tegas.

Orang-orang yang kodependen terus menerus mengkhawatirkan perasaan orang lain, sampai pada titik menjadi sakit secara emosi dan fisik. Ketika mereka berhadapan dengan siapapun yang marah atau sedih, reaksi mereka yang pertama adalah memikirkan apakah yang telah mereka lakukan sehingga membuat orang itu marah. Intinya, masalah kodependensi mencakup cara-cara seseorang mengatasi perilaku dan tuntutan dari orang-orang di sekitarnya [11],[12].

Test untuk mengetahui apakah anda pemimpin kodependen

1: Sangat tidak setuju; 2: tidak setuju; 3: ragu-ragu; 4: setuju; 5: sangat setuju

Tabel 1. Test pemimpin kodependen

\begin{tabular}{|c|c|}
\hline $\begin{array}{l}\text { Saya tumbuh di dalam keluarga dengan satu atau lebih orang-orang yang } \\
\text { dependen pada substansi (alkoholik, pecandu obat-obatan, pencandu } \\
\text { makanan, dan lain-lain) }\end{array}$ & 12345 \\
\hline $\begin{array}{l}\text { Saya bertumbuh di dalam lingkungan yang kaku, legalistic, yang } \\
\text { memperlakukan standard perilaku yang tidak realistic kepada anggota } \\
\text { keluarga dan melarang diskusi yang terbuka, jujur, mengenai masalah- } \\
\text { masalah dan pergumulan pribadi }\end{array}$ & 12345 \\
\hline $\begin{array}{l}\text { Saya biasanya toleran atau mengabaikan perilaku orang-orang lain yang aneh, } \\
\text { memalukan dan yang tidak patut }\end{array}$ & 12345 \\
\hline $\begin{array}{l}\text { Saya sering menghindari dari membagikan pendapat saya di dalam tatanan } \\
\text { kelompok kecil sampai saya sudah mendengar pendapat dari orang lain di } \\
\text { dalam kelompok itu }\end{array}$ & 12345 \\
\hline $\begin{array}{l}\text { Saya sering kali khawatir melukai perasaan orang lain jika membagikan } \\
\text { perasaan dan pemikiran saya yang sebenarnya }\end{array}$ & 12345 \\
\hline $\begin{array}{l}\text { Saya sering merasa bertanggung jawab atas masalah-masalah yang tidak saya } \\
\text { buat }\end{array}$ & 12345 \\
\hline Saya sulit tidur karena mengkhawatirkan masalah atau perilaku seseorang & 12345 \\
\hline $\begin{array}{l}\text { Saya dapati diri saya seringkali terlalu mengabdi dan merasa hidup saya sudah } \\
\text { tidak terkendali }\end{array}$ & 12345 \\
\hline $\begin{array}{l}\text { Saya merasa amat sangat sulit mengatakan "tidak" kepada orang lain } \\
\text { walaupun saya tahu bahwa mengatakan ya akan mengakibatkan kesulitan bagi } \\
\text { saya dan keluarga }\end{array}$ & 123345 \\
\hline $\begin{array}{l}\text { Saya secara konstan merasakan suatu citra bersalah namun kesulitan mencari } \\
\text { sumbernya }\end{array}$ & 12345 \\
\hline $\begin{array}{l}\text { Saya merasa seperti tidak pernah cocok dengan mereka yang ada di sekitar } \\
\text { saya dan memiliki pikiran mencela diri }\end{array}$ & 12345 \\
\hline $\begin{array}{l}\text { Ketika saya menerima penghormatan dari orang lain, saya merasa sulit hanya } \\
\text { sekedar menerimanya tanpa membuat pernyataan yang memenuhi syarat }\end{array}$ & 12345 \\
\hline
\end{tabular}

Jumlahkan bilangan yang dilingkari dan tempatkan jumlahnya di sini:

Jika jumlah anda kurang dari 20, mungkin anda bukan kodependen. Jika jumlah anda di antara 21 dan 40, ada kemungkinan anda memiliki beberapa kecenderungan kodependen. Jika jumlah anda adalah 41 atau lebih, anda mungkin adalah seorang pemimpin yang kodependen.

\subsection{Pemimpin Pasif-Agresif}

Banyak pemimpin pasif-agresif merasa sulit menentukan sasaran-sasaran dan menetapkan rencanarencana masa depan karena ada kemungkinan menemukan kegagalan. Ketakutan ini ditambah dengan pandangan pesimistik dari para pemimpin pasif-agresif, menyebabkan mereka mengatakan, "Apakah gunanya merencanakan dan menetapkan sasaran?; bagaimanapun tidak ada yang akan berubah di sekitar sini”. Dengan 
enggan mereka melaksanakan rencana-rencana majelis mereka. Standar dan sistem penilaian terhadap penampilan, biasanya dibenci dan ditolak oleh pemimpin yang pasif-agresif.

Para pemimpin pasif-agresif bisa mengeluh terus-menerus tentang tidak adanya dukungan dari dewan dan mereka yang dipimpin, mengulang-ulang tidak adanya dukungan itu adalah salah satu alasan terganggunya efektifitas mereka. Ironisnya, ketika orang lain terlibat dengan mereka dan dengan minat yang serius, sungguhsungguh berniat untuk menolong mereka, para pemimpin ini segera mengeluh bahwa mereka tidak diijinkan untuk memimpin sesuka mereka. Dalam pertemuan majelis atau situasi lain, seperti pertemuan serius, pemimpin pasif-agresif bisa menjadi tidak sabar dan lekas marah ketika ada hal-hal yang tidak sesuai dengan maksudnya. Frustasi ini sering menyebabkan ledakan emosi saat itu atau pada suatu ketika kelak di dalam pertemuan yang tidak berkaitan sama sekali. Masalahnya, bukanlah para pemimpin ini selalu marah dan mengeluh. Umumnya, mereka terlihat bahagia, taat dan puas dengan pekerjaan dan organisasi mereka. Akan tetapi, pola perilaku emosional yang tidak terduga hanya dapat terlihat setelah satu jangka waktu, karena pola ini, para pemimpin yang pasif agresif sering menjadi bulan-bulanan lelucon dan pembicaraan kalangan inti seperti, "Saya bingung siapa yang akan muncul malam ini?" atau "saya pasti berharap orang ini tidak memberikan pertunjukkan malam ini”[11],[12].

Test untuk mengetahui apakah anda pemimpin pasif-agresif

1: Sangat tidak setuju; 2: tidak setuju; 3: ragu-ragu; 4: setuju; 5: sangat setuju

Tabel 2. Test pemimpin pasif-agresif

\begin{tabular}{|l|r|}
\hline $\begin{array}{l}\text { Saya dapati diri saya menolak standard an prosedur untuk peninjauan formal } \\
\text { atas penampilan saya }\end{array}$ & 12345 \\
\hline $\begin{array}{l}\text { Sudah biasa bagi saya untuk menangguhkan proyek-proyek utama yang harus } \\
\text { saya lakukan }\end{array}$ & 12345 \\
\hline $\begin{array}{l}\text { Saya selalu menolak ide-ide orang lain yang bisa menyebabkan bertambahnya } \\
\text { pekerjaan atau tanggung jawab bagi saya }\end{array}$ & 12345 \\
\hline Saya dapati diri saya selalu berkinerja di bawah kemampuan saya & 12345 \\
\hline $\begin{array}{l}\text { Saya mengalami ledakan-ledakan periodic namun berulang ulang dari } \\
\text { kemarahan dan frustasi yang hanya berada di dalam batas-batas dari apa yang } \\
\text { dianggap perilaku yang dapat diterima }\end{array}$ & 12345 \\
\hline Kadang kala secara sengaja saya melupakan proyek yang diusulkan & 12345 \\
\hline $\begin{array}{l}\text { Kadang kala saya berdiam diri sebagai ungkapan kemarahan saya kepada orang } \\
\text { lain }\end{array}$ & 12345 \\
\hline $\begin{array}{l}\text { Saya dapati diri saya mengatakan kepada orang lain bahwa tidak ada yang } \\
\text { menganggu saya, ketika kenyataannya bahwa saya sedang geram }\end{array}$ & 12345 \\
\hline $\begin{array}{l}\text { Saya cenderung menjadi pesimistik secara umum dan merasa negative tentang } \\
\text { masa depan saya }\end{array}$ & 12345 \\
\hline $\begin{array}{l}\text { Orang lain telah mengungkapkan kepada saya bahwa saya membuat mereka } \\
\text { merasa tidak nyaman }\end{array}$ & 12345 \\
\hline $\begin{array}{l}\text { Perencanaan strategi dan penentuan sasaran itu sulit bagi saya dan saya menolak } \\
\text { penerapan seperti ini }\end{array}$ & 12345 \\
\hline $\begin{array}{l}\text { Kadangkala saya sadar saya mencoba menipu orang lain di dalam banyak } \\
\text { setting kelompok dengan melepaskan kemarahan dan emosi saya ketika } \\
\text { menghadapi inisiatif yang tidak saya dukung }\end{array}$ & 12345 \\
\hline
\end{tabular}

Jumlahkan bilangan yang dilingkari dan tempatkan jumlahnya di sini:

Jika jumlah anda kurang dari 20, mungkin anda bukan pasif-agresif. Jika jumlah anda di antara 21 dan 40, ada kemungkinan anda memiliki beberapa kecenderungan pasif-agresif. Jika jumlah anda adalah 41 atau lebih, anda mungkin adalah seorang pemimpin yang pasif-agresif. 


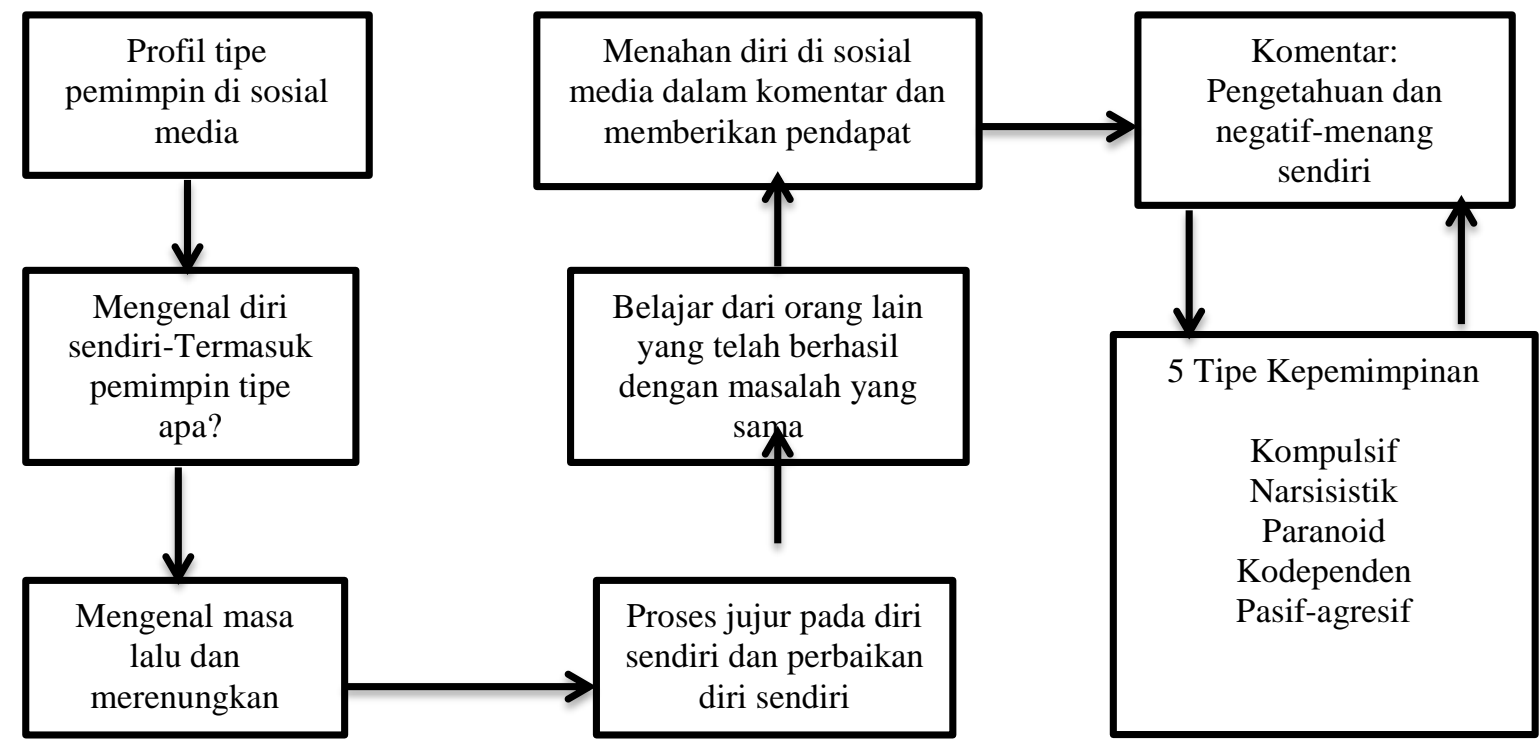

Gambar 2. Proses pendewasaan dalam komunikasi- final framework

Pada gambar 2, kita dapat melihat bahwa proses terpenting di awal adalah mengerjakan semua mini test untuk dapat mengetahui kita termaksud dalam tipe kepemimpinan seperti apa, rumusan ini dapat dihasilkan dari test yang didapat, sebagai contoh, hasil dari 5 tipe kepemimpinan:

Hasil test pemimpin kompulsif: 20; hasil test pemimpin narsisitik: 40 (50\%); hasil test pemimpin paranoid: 45 ; Hasil test pemimpin kodependen: 20; Hasil test pemimpin pasif-agresif: 50, hasil test ini menjelaskan bahwa seseorang tidak memiliki jiwa kepemimpin pada sisi kompulsif dan kodependen, tetapi memiliki sisi kepemimpinan pasif-agresif yang dominan, dan juga memiliki jiwa kepemimpinan paranoid dan terakhir adalah memiliki 50\% jiwa kepemimpinan narsisistik. Dengan demikian, dengan jelas, gaya komunikasi dan statemen-statemen yang dilontarkan tentunya dapat diketahui bahwa kita dapat mengenal diri kita sendiri dalam tipe tertentu.

Tahap berikutnya adalah kita harus dapat mengetahui sifat-karakter-sikap dan gaya komunikasi saat ini, yang dipengaruhi oleh masa lalu kita sendiri; proses ini merupakan sebuah proses perenungan dan perbaikan diri untuk dapat mengetahui kekuatan dan kelemahan di dalam diri serta mengetaui trauma dan hal-hal negatif apa saja yang mempengaruhi sikap dan gaya komunikasi kita pada saat ini. Setelah mendapatkan jawaban atas permasalahan yang ada, maka tahap berikutnya adalah mempelajari biografi, orang-orang yang sudah mencapai keberhasilan dan tentunya, kita harus dapat menemukan pemimpin dengan tipe seperti hasil test seperti apa yang telah berhasil menjadi sukses dan dapat melewati permasalahan yang ada. Perbaikan itu harus dimulai dari diri sendiri, bukan dari lingkungan, lingkungan tidak mungkin menyesuaikan diri dengan diri kita, tetapi kita harus menyesuaikan dengan kondisi yang ada, tetapi di sini perlu diingat, penyesuaian adalah merupakan sebuah bentuk berbahaya yang jika salah menafsirkan ini akan berakibat kerusakan pada mentalitas, spiritualitas dan seluruh keseharian di dalam hidup kita. Penyesuaian artinya kita mampu dalam menyesuaikan diri dengan orang lain dan/atau lingkungan dengan batasan yang perlu kita jaga, karena batasan harus selalu ada agar kita tidak dipengaruhi sepenuhnya, pengaruh-pengaruh yang ada harus dapat dipisahkan dan dipilahpilah, mana yang dapat membuat diri kita menjadi semakin baik dan mana yang membuat diri kita semakin buruk dan tidak memberikan faedah apapun, di sinilah yang disebut sebagai dewasa secara penuh, karena dewasa secara penuh artinya orang yang mampu memilih secara benar dan tepat apa yang diperlukannya dan bukan diinginkannya, yang kemudian, dieksekusi menjadi sebuah tindakan yang pada akhirnya menjadi sebuah perilaku yang menentukan kesuksesan dan/atau kegagalan. Proses perbaikan inilah yang menjadi fokus pada pemimpin dan di sinilah pengaruh pemimpin di sosial media akan dapat semakin besar dan/atau semakin kecil, semakin memberikan dampak/kontribusi positif dan/atau dampak/kontribusi negatif kepada masyarakat.

Proses berikutnya kemampuan dalam menahan diri di dalam sosial media, kemampuan ini dimiliki oleh setiap orang, tetapi banyak tidak mau menggunakannya dan/atau bahkan tidak peduli untuk menggunakan hal tersebut. kemampuan menahan diri artinya: kemampuan dalam melihat informasi yang berada di sosial media, yang kemudian dapat diolah di dalam pikiran berdasarkan pengetahuan yang dimiliki, kemudian berusaha 
mencari informasi terlebih dahulu sebelum memberikan statemen tertentu yang dapat memicu kegaduhan. Pertanyaannya adalah apakah kita tidak boleh mengemukakan pendapat?, kita dapat mengemukakan pendapat, tetapi tentunya ada beberapa persyaratan penting yang perlu dipahami terlebih dahulu, yaitu sebelum kita berkomentar, kita harus memiliki pengetahuan dan pengalaman yang cukup untuk topik dan kalimat yang ingin kita komentari, hal ini dapat mengurangi perdebatan yang tidak penting di dalam sosial media, perdebatan yang hanya memicu masalah semakin besar dan tidak dapat diselesaikan, dan bahkan masalah tersebut dapat merusak seluruh lingkungan tersebut tanpa dapat dihentikan.

\subsection{Pemimpin dan Solusi}

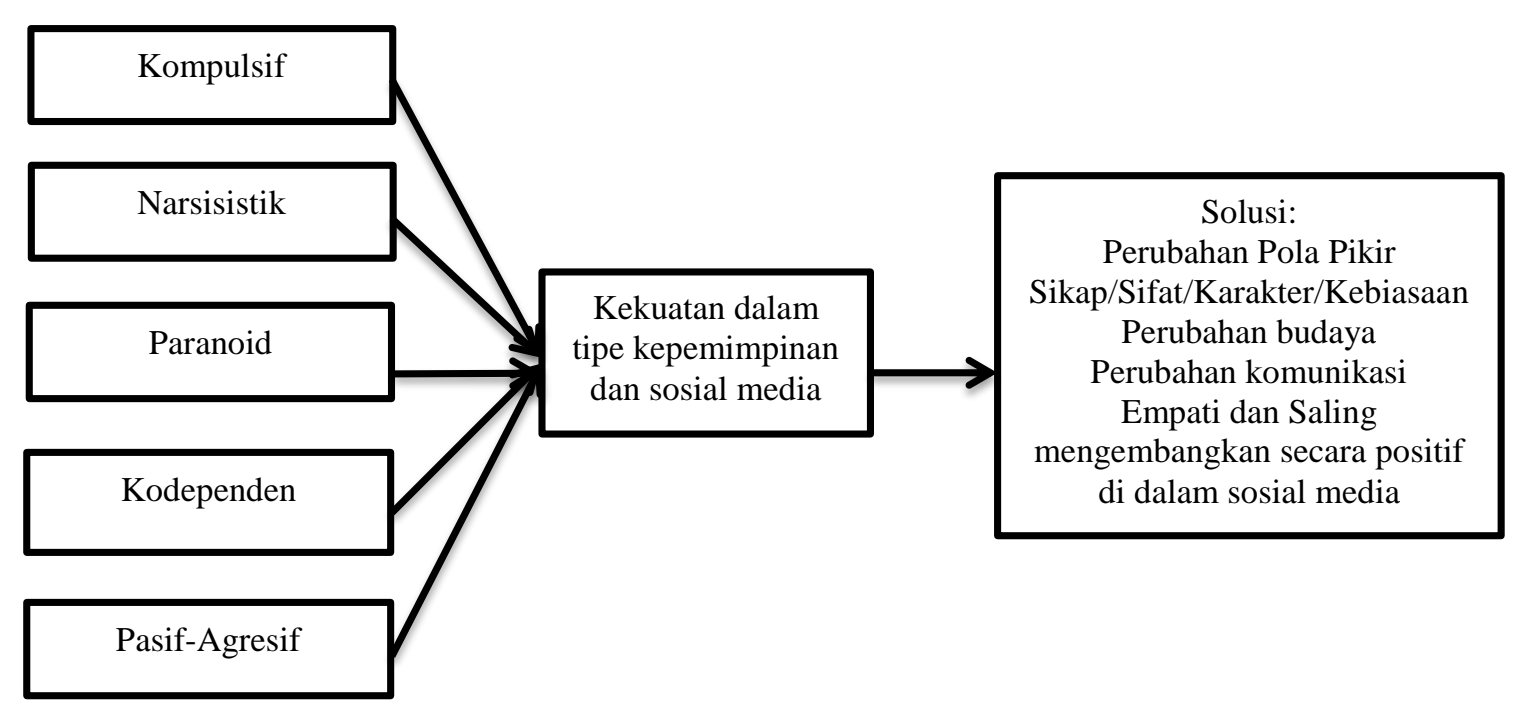

Gambar 3. Leadership intelligence (FI) framework

Pada gambar 3, dapat lihat bahwa 5 tipe kepemimpinan ini merupakan sebuah standarisasi pada sosial media. Kelima tipe kepemimpinan tersebut antara lain: kompulsif, narsisistik, paranoid, kodependen, pasifagresif. Sekarang, masuk pembahasan dan hasil akhir, yaitu tentang bagaimana komentar dan solusi yang seharusnya dimiliki oleh ke 5 tipe kepemimpinan tersebut. Komentar adalah sebuah lontaran kalimat dari pikiran dan hati kita kepada orang lain dan/atau terhadap sesuatu dan hal tersebut berupa sebuah statemen yang memiliki makna tertentu di balik kalimat tersebut. Pemimpin seharusnya memiliki beberapa tahap dalam mengemukakan komentar: pertama- komentar tersebut harus dapat memberikan pengetahuan umum dan khusus kepada masyarakat, pengetahuan umum artinya definisi-definisi tertentu yang harus diketahui dan dipelajari oleh masyarakat dan tentunya pemimpin harus memberitahukan penjelasan sumber dari definisi tersebut, apakah berasal dari kamus dan/atau dari pemahaman pemimpin atas konsep tertentu. Sebagai contoh: kita harus memahami apa artinya berkomunikasi dengan baik dan benar, kata pemimpin, maka berikutnya seorang pemimpin harus dapat menjelaskan: komunikasi artinya sebuah proses di mana informasi dipertukarkan antara individu melalui sistem umum simbol, tanda, atau perilaku, menurut Merriam Webster dictionary. Pada hari ini saya akan menjelaskan kepada saudara-saudara sekalian dengan menggunakan beberapa contoh bagaimana cara berkomunikasi yang baik dan benar... Di kalimat tersebut dapat dilihat sebuah penekanan penting, yaitu pada komunikasi artinya dan menurut siapa, itu yang disebut pengetahuan umum. Berikutnya adalah contoh dari komunikasi yang baik adalah...., ini adalah merupakan pengetahuan khusus, dimana seorang pemimpin mengajarkan bagaimana pengetahuan tersebut dapat diimplementasikan di dalam kehidupan sehari-hari. Dari beberapa contoh diatas dapat disimpulkan sebagai berikut: seorang pemimpin harus dapat menggunakan contoh konkrit dan data dalam menjelaskan sesuatu, sehingga dapat meningkatkan pengetahuan kepada masyarakat dan dapat memberikan inpisrasi perubahan secara positif.

Beberapa komentar yang tidak memberikan faedah positif dan/atau kontribusi positif kepada masyarakat sebisa mungkin untuk dapat ditahan agar tidak terlontar keluar, karena hal ini akan dapat mengakibatkan perubahan suasana menjadi lebih negatif dan menimbulkan sebuah kericuhan yang tidak penting. Perlu dipahami, kerusakan terkadang dapat ditimbulkan dari pembicaraan yang seharusnya tidak dilontarkan, mungkin bermaksud baik, tetapi cara penyampaian salah, maka hasilnya pun menjadi salah, sesuatu yang memiliki tujuan baik, tetapi memiliki cara yang salah, akan menghasilkan kerusakan proses komunikasi, oleh sebab itu seorang pemimpin hendaknya dapat berpikir secara terintegrasi, yang artinya sebelum melontarkan dan menjelaskan sesuatu, harus dapat mengecek apa tujuan sebenarnya dari kalimat dan penjelasan tersebut? dan kemudian harus memikirkan cara apa yang tepat dalam menyampaikannya sehingga tidak terjadi hal-hal 
negatif yang tidak penting. Masyarakat kita sudah terlalu berat dalam menghadapi berbagai beban hidup, oleh sebab itu, beban yang berat ini, seharusnya dapat dikurangi dengan memberikan harapan positif tetapi dengan menggunakan penjelasan berupa data-data konkrit dan contoh agar masyarakatpun dapat ikut berpikir untuk memberikan solusi.

Hal yang tidak kalah penting di sini adalah solusi, solusi adalah merupakan salah satu hal terpenting di dalam komunikasi sosial media. Solusi belum tentu merupakan pemecahan masalah dari permasalahan tersebut, solusi terkadang dapat menimbulkan efek negatif jika kita salah melontarkan solusi, dan solusi dapat memberikan dampak positif, jika solusi tersebut dapat memberikan perubahan ke dalam kehidupan masyarakat. Sebagai contoh: kita mengkritik bahwa banjir tidak pernah diselesaikan di daerah tertentu, seorang pemimpin yang baik akan melontarkan sebuah contoh studi kasus dari Negara lain dan/atau kota/daerah dan/atau teknologi yang sudah pernah diterapkan di sebuah lokasi untuk dapat mengatasi banjir, dan melontarkan ini di sosial media, untuk menanyakan kepada masyarakat, apakah ada masukan dalam menerapkan ini di kota ini?, masyarakat tentunya dituntut untuk dapat memberikan masukannya dengan pengetahuan, bukan mengatakan saja, setuju dan tidak setuju, tetapi harus dapat memberikan solusi untuk hal tersebut, mungkin ada contoh lainnya yang dapat diterapkan dan dijadikan masukan untuk pemimpin di pemerintahan sehingga terjadi komunikasi dua arah antara pemimpin dan masyarakat, saling mencerdaskan adalah hal lumrah dan sangat positif dan dapat dilakukan. Oleh sebab itu, inilah yang disebut cara positif di dalam berkomunikasi antara pemimpin dan masyarakat, kita semua mungkin mampu melontarkan kritik dan mengekspos kesalahankesalahan orang lain dan mengiklankan hal tersebut, tetapi kebanyakan dari kita, kita tidak berani jika mengiklankan kesalahan yang pernah dibuat oleh diri kita sendiri, perlu dipahami kesempurnaan datang dari ketidaksempurnaan, karena ketidaksempurnaan merupakan sebuah bentuk perkembangan menuju kedewasaan. Jika hal ini dapat dipahami dengan benar, karena secara jujur, sulit sekali menuntut sesuatu untuk sangat sempurna tetapi ketidaksempurnaan itulah yang membantu kita untuk survive dan mengalami perubahan secara positif, dan di sinilah timbul dan berkembang inovasi-inovasi dalam pemecahan masalah, masalah harus dipecahkan dengan inovasi baru yang merupakan pengembangan dari inovasi sebelumnya.

\section{KESIMPULAN}

Kepemimpinan di sosial media merupakan sebuah tantangan terbesar yang ada, dimana perubahan budaya bersosial media merupakan faktor terpenting yang perlu dicermati dan dikembangkan dengan sangat hati-hati, karena perubahan ini akan dapat menimbulkan efek jangka panjang bagi para penggunanya dan orang pada umumnya. Tipe-tipe kepemimpinan di sosial media merupakan tipe-tipe yang perlu banyak dipahami oleh masyarakat, karena para pengguna sosial media sampai saat ini, masih meraba, tipe kepemimpinan seperti apa yang seharusnya dihormati, didengar dan ditaati.

\section{REFERENSI}

[1] I. Gamayanto, "Pengembangan dan Implementasi dari Wise Netizen ( E- Comment ) di Indonesia," techno.com, vol. 16, no. 1, pp. 80-95, 2017.

[2] R. N. indra gamayanto Pratikna and I. Gamayanto, "Developing Leadership Systems Inside University Using Jim Collins Method [ Good to Great ]: People Management Development to Face ASEAN Economic Community in Indonesia," in Review of Integrative Business and Economics Research, 2017, vol. 6, no. 3, pp. 45-55, [Online]. Available: http://buscompress.com/journal-home.html.

[3] C. Voegtlin, M. Patzer, and A. G. Scherer, "Responsible Leadership in Global Business: A New Approach to Leadership and Its Multi-Level Outcomes," J. Bus. Ethics, vol. 105, no. 1, pp. 1-16, 2012, doi: 10.1007/s10551011-0952-4.

[4] S. A. Eisenbeiß and F. Brodbeck, "Ethical and Unethical Leadership: A Cross-Cultural and Cross-Sectoral Analysis,” J. Bus. Ethics, vol. 122, no. 2, pp. 343-359, 2014, doi: 10.1007/s10551-013-1740-0.

[5] D. Wang, T. Feng, and A. Lawton, "Linking Ethical Leadership with Firm Performance: A Multi-dimensional Perspective," J. Bus. Ethics, vol. 145, no. 1, pp. 95-109, 2017, doi: 10.1007/s10551-015-2905-9.

[6] E. J. Garcia, "Raising leadership criticality in MBAs," High. Educ., vol. 58, no. 1, pp. 113-130, 2009, doi: 10.1007/s10734-008-9185-6.

[7] D. T. Kong and R. Volkema, "Cultural Endorsement of Broad Leadership Prototypes and Wealth as Predictors of Corruption," Soc. Indic. Res., vol. 127, no. 1, pp. 139-152, 2016, doi: 10.1007/s11205-015-0959-9.

[8] J. E. Wells and T. J. Aicher, "Follow the Leader: A Relational Demography, Similarity Attraction, and Social Identity Theory of Leadership Approach of a Team's Performance," Gender Issues, vol. 30, no. 1-4, pp. 1-14, 2013, doi: 10.1007/s12147-013-9112-8. 
[9] B. Nooteboom, "Discussion of leadership and cultural change: an economic analysis," no. 4, pp. 439-452, 2002.

[10] L. R. Men, "Internal reputation management: The impact of authentic leadership and transparent communication," Corp. Reput. Rev., vol. 17, no. 4, pp. 254-272, 2014, doi: 10.1057/crr.2014.14.

[11] F. Alzami, S. Novianto, and I. Gamayanto, "Designing the Concept of Leaderships Intelligence (CI2.1) Version 2.0 inside Social Media Using Ken Watanabe Problem Solving 101 Methods," in 2020 International Conference on Decision Aid Sciences and Application, DASA 2020, 2020, doi: 10.1109/DASA51403.2020.9317113.

[12] L. M. Miller, "A Positive Psychology Theoretical Model to Coach Veterans Through Successful Transitions," Adv. Dev. Hum. Resour., vol. 19, no. 1, pp. 25-35, 2017, doi: 10.1177/1523422316682735. 